Kasperè, R. and Motiejūnienè, J. (2021). Impacts of global pandemic on translator's career and translator training. Current Trends in Translation Teaching and Learning E, 8, 154 - 195. https://doi.org/10.51287/cttle 20216

\title{
IMPACTS OF GLOBAL PANDEMIC ON TRANSLATOR'S CAREER AND TRANSLATOR TRAINING
}

Ramunė Kasperè and Jurgita Motiejūnienè

Kaunas University of Technology

\section{Abstract}

The translation market as well as many other businesses and activities have been affected by the lockdown of economies in the whole world since the beginning of 2019. Under the impacts of COVID-19 pandemic, translator's career has undergone some major and minor transformations. Some recent research papers have focused on crisis-related situations and emphasised the fact that translators need to be ready to ensure an effective communication between all stakeholders in disaster settings (Rodriguez Vazquez \& Silvia Torres del Rey, 2020). Therefore, the methods and approaches in translation training have to be reexamined in order to provide language support in crises (Federici \& O'Brien, 2019). This research was designed to examine and depict the effects of the global pandemic and the lockdown on the translator's profession and translator training in graduate and postgraduate education. The paper analyses the insights and attitudes expressed in surveys by different players in the Lithuanian translation market, including freelance translators and interpreters, language service providers and translation students. The results highlight different opinions of 
Kasperè, R. and Motiejūnienè, J. (2021). Impacts of global pandemic on translator's career and translator training. Current Trends in Translation Teaching and Learning E, 8, 154 - 195. https://doi.org/10.51287/cttle 20216

freelance translators and translation students about the future of their career, trust of freelance translators towards the state support and translation agencies at which they are hired, and anxiety of language service providers towards the stability of the industry in crises situations. The results of the research further indicate the necessity to develop translation study programmes focussing on a wider skillset so that future translators would be well equipped to contribute to communication and well-being of different members of society in crisis settings.

Keywords: COVID-19, pandemic, translator training, translation industry, language service providers, LSPs.

\section{INTRODUCTION}

The lockdown of economies worldwide since March of 2020 due to the global COVID-19 pandemic has made huge impacts on industries, including the translation business world. The working practices within the translator's job have undergone transformations, resulting in changed future prospects of the translator's profession.

In recent research within the translation studies field related to crisis translation, emphasis has been placed on the need for translators to ensure an effective communication between all stakeholders in disaster settings (Rodriguez Vazquez \& Silvia Torres del Rey, 2020; Zhang \& Wu, 2020; Veliz-Ojeda et al., 2020). In a study by Alexander and Pescaroli (2019), 
Kasperè, R. and Motiejūnienè, J. (2021). Impacts of global pandemic on translator's career and translator training. Current Trends in Translation Teaching and Learning E, 8, 154 - 195. https://doi.org/10.51287/cttle 20216

researchers explain the significance of crises for translators and interpreters, and how their work may be affected by such events. The authors identify situations in which translation is important in successful preparation for emergencies. However, there is very scarce research to directly investigate the impact of crises like the COVID-19 pandemic on the translation market, translator's profession and translation training. Crisis situations present considerable challenges and have negative and potentially positive consequences, which have to be determined and defined in order to persevere and reduce possible damage. The position of translation and translators in crisis response is important to consider.

On the other hand, translator training needs have to be refined in order to train future translators to provide efficient language support in crises (Federici \& O'Brien, 2019), especially following the consequences and implications of crises like the global COVID-19 pandemic. In relation to the demands for competences and qualifications that translators need to have to facilitate and mediate communication, their own well-being, perceptions, attitudes and reactions need to be addressed.

This study, therefore, is aimed at discussing and describing the effects of the pandemic and the lockdown on the translator's profession as well as on 
Kasperè, R. and Motiejūnienè, J. (2021). Impacts of global pandemic on translator's career and translator training. Current Trends in Translation Teaching and Learning E, 8, 154 - 195. https://doi.org/10.51287/cttle 20216

crisis-related translator training at both undergraduate and graduate study levels. The paper presents an analysis of opinions and attitudes of freelance translators and interpreters, heads of language service providers (LSPs) and translation trainees.

\section{CONTEXT AND ISSUE IN QUESTION. RELATED WORK}

Crises like the 2019-2021 global COVID-19 pandemic have shown that translation is more than ever considered to be among the first measures to overcome miscommunication, disinformation and general lack of access to information. Since 2020, some important papers have been published "accentuating the need for translation in the fight against Covid-19”' (Piekkari et al., 2021; Luo, 2021). To meet the urgent needs of multilingual communication, different translation-related means have been taken.

Zhang and $\mathrm{Wu}$ (2020) describe the role of crowdsourced translations and translators volunteering to reduce the overall undesirable impacts and acknowledge that the issue has been underestimated and unresearched. They conclude that policy-makers should prepare for abandoning "English monolingual ideologies" and need to develop strategies to address the needs of 
Kasperè, R. and Motiejūnienè, J. (2021). Impacts of global pandemic on translator's career and translator training. Current Trends in Translation Teaching and Learning E, 8, 154 - 195. https://doi.org/10.51287/cttle 20216

linguistically diverse ethnic populations (Zhang \& $\mathrm{Wu}, 2020)$. The suggestion behind this conclusion is that countries are in need to strengthen the linguistic measures by possibly addressing the issue of the importance of translation and properly qualified translators.

Zheng (2020) has reported of a case when volunteer foreign language students have been used as "readily available multilingual resources" mobilized for crisis translation (p. 587). The study has revealed a number of challenges experienced in emergency situations, like temporal constraints, insufficient language proficiency and inadequate technical knowledge of volunteering students, and has suggested that measures be taken for creation of appropriate language provision in crisis communication (Zheng, 2020).

In another study, authors (O'Mathuna et al., 2020) claim that citizen translators, i.e., those who have not completed professional translation training, can contribute in crisis situations that require quick decision making. According to them, translation and interpreting can possibly improve "access to crucial safety information" (ibid.). Federici \& Cadwell (2018) also stress the crucial role of citizen translators and interpreters when assisting NGOs experiencing critical situations and raised the questions of what 
Kasperè, R. and Motiejūnienè, J. (2021). Impacts of global pandemic on translator's career and translator training. Current Trends in Translation Teaching and Learning E, 8, 154 - 195. https://doi.org/10.51287/cttle 20216

training materials would be useful in preparing them for this role.

Machine translation has also been appropriated in various urgent situations when citizens had to be informed as soon as possible in order to avoid risk and receive the necessary care, treatment or support services. Recently representatives of the Australian government used machine translation to communicate about COVID-19, a high-risk topic, to multilingual communities (Dalzell, 2020). Reliance on these technologies has grown to the extent that they are being used for personal and public purposes, albeit possibly with no clear understanding of the quality they generate. Rossetti et al. (2020) carried out a survey in order to perceive the impact of machine translation and postediting awareness with regard to comprehension of and trust in messages sent to the public in a weather-related crisis. They concluded that that plain language and/or translation could play a significant role in crisis when establishing trust between different emergency managers and the public, and in such a way, help the public prepare for crisis situations (ibid.).

Such instances and many more demonstrate that translation and translators are expected to take a significant leading role and a cooperative initiative in helping communities to solve problems and 
Kasperè, R. and Motiejūnienè, J. (2021). Impacts of global pandemic on translator's career and translator training. Current Trends in Translation Teaching and Learning E, 8, 154 - 195. https://doi.org/10.51287/cttle 20216

overcome real and serious challenges. Yet, it is essential to discuss the translators' behaviours and reactions towards the events and practices that evolve into certain societal expectations from the profession. It comes with no surprise that translators are affected by crises not only like any other professionals, but also like humans, members of society, ordinary people.

There have been recently several attempts to overview how the translators' community has reacted to the global effects throughout the lockdowns, how translation practices have changed, transformed, and diversified to adapt to current challenges and how the translator's profession has been emerging as a crucial service. At the national levels in different countries, attention has been paid to the necessity of ensuring the wellbeing of translators as well as other professionals and freelancers working for the benefit of society. FIT Europe, the Regional Centre of the International Federation of Translators (FIT) (represents around 40,000 language professionals across Europe, including translators, interpreters, terminologists, researchers and trainers), has started gathering information about how freelance translators and interpreters are covered by the existing measures or the measures that are now being announced by governments in response to the crisis. Many states have introduced measures to support freelancers in 
Kasperè, R. and Motiejūnienè, J. (2021). Impacts of global pandemic on translator's career and translator training. Current Trends in Translation Teaching and Learning E, 8, 154 - 195. https://doi.org/10.51287/cttle 20216

this difficult time, such as a fixed amount of monetary support, daily allowances for forced parental leave, postponed electricity, water and gas bills, postponed tax installments and social security contributions, suspended mortgage payments, deferred business loans, rent freezes and bans on evictions, faster VAT refunds, no penalties for late VAT filing, etc. (O’Shea, 2020).

The European Council of Literary Translators' Associations (CEATL) have accumulated reactions of translators from across European countries about the impacts of the pandemic and lockdowns on translators (2020). Although many countries have introduced various proposals for self-employed professionals, including translators and interpreters, the overview provides that effects of the pandemic consequences on translators may have been harsh, as contractors and agencies in different countries have cancelled their payments forcing translators to overcome the losses on their own grounds (CEATL, 2020).

It appears that translation markets all over the world have experienced negative outcomes of the pandemic. Wang et al. (2020) have assessed the effects of this world crisis on language service providers, including translators, in China and have noted abrupt and extreme consequences, like loss of business, drops of 
Kasperè, R. and Motiejūnienè, J. (2021). Impacts of global pandemic on translator's career and translator training. Current Trends in Translation Teaching and Learning E, 8, 154 - 195. https://doi.org/10.51287/cttle 20216

income, adjustments of business models, high-rate negative effects on services related to English, and an indispensable need for support from local and national authorities.

Besides the various pandemic-related effects on the translators' professions and practice and the measures taken by governments to protect and support freelance professionals, researchers, instructors and study implementers need to focus on and find the ways to enable future professionals to adapt to various emergencies and crises in the translation market. The instances of different translation practices point to the need for a change of focus in translator training. Future translation professionals should be able to not only develop their professional and technical skills but also be ready to more substantially engage in personal development in order to overcome external challenges and provide the best possible linguistic, translation and mediation services, thus satisfying the needs of society in crises.

In this regard, the academia has a few questions to consider. One of the most important issues is the challenge of teaching traditional professions and training specialists who will have to deal with future challenges in environments that have just now been changed - from conventional contact modes to virtual remote ways. In the period of the pandemic and 
Kasperè, R. and Motiejūnienè, J. (2021). Impacts of global pandemic on translator's career and translator training. Current Trends in Translation Teaching and Learning E, 8, 154 - 195. https://doi.org/10.51287/cttle 20216

lockdowns, many translator training institutions have been obliged to transfer all or some study and learning activities to virtual environments, which has of course one way or another to a greater or lesser extent positively or negatively affected the intake of theoretical knowledge and practical skills, has interfered with simulation-based tasks that have recently become an integral part of the study process, very much appreciated by students. Although the focus of researchers working within the topics of training of professionals has quickly moved to current challenges of online education, to the use of digital tools and platforms in educational settings and to overall trends of current crisis-induced teaching transformations, studies addressing the perceptions of future translation and interpreting professionals are still sporadic. Translation trainers, instructors and study programme developers and implementers need not only to consider how crises-related practices are changing the content that has to be taught and the ways how competences need to be trained, but also how changes affect students' understanding of their professional career future.

The core documents in translator training define and describe the competences required for professionals to have. The documents and regulations that are followed include the EMT competence framework, the ISO Translation services standards: 17100 
Kasperè, R. and Motiejūnienè, J. (2021). Impacts of global pandemic on translator's career and translator training. Current Trends in Translation Teaching and Learning E, 8, 154 - 195. https://doi.org/10.51287/cttle 20216

standard on Requirements for translation services and 18587 standard on Post-editing of machine translation output, as well as other ISO standards, professional standards in the industry, codes of ethics and other regulating and guiding documents. Some research papers have also been published (Krajcso, 2018). Based on European initiatives on translators' competence profiles and the results of translation industry surveys, professional competence followed by technological and domain competence is found the most essential requirement for a translator (Krajcso, 2018).

Taking into consideration the guidelines and recommendations of regulating institutions, the expectations of the industry and society, and the perceptions of translators already in the trade as well as future professionals that are currently translation trainees may provide theoretical, pedagogical and evidence-based practical implications concerning the translator training for the needs of society in unpredictable circumstances of the current global COVID-19 pandemic.

\section{METHODOLOGY AND MATERIALS}

For the purposes of this research, during the first lockdown, in May and June, 2020, a survey was conducted in order to determine the attitudes and 
Kasperè, R. and Motiejūnienè, J. (2021). Impacts of global pandemic on translator's career and translator training. Current Trends in Translation Teaching and Learning E, 8, 154 - 195. https://doi.org/10.51287/cttle 20216

experiences of different players in the Lithuanian translation market. An emphasis in the survey was put on the dynamics in the numbers and nature of translation orders as well as behaviour of clients, LSPs and the state support. In total, 65 freelance translators and 21 LSPs were surveyed. The surveys were multidimensional, covering different questions, e.g., whether freelancers and LSPs have noticed the changes in the numbers of orders, language pairs, type and domain of texts, prices, loss of clients, whether they knew about the state support, etc. (see Appendix 1 for a questionnaire of LSPs and Appendix 2 for a questionnaire of freelance translators and interpreters). At the beginning of 2021, another survey was conducted, focussing on translator training and students' experiences as well as perceptions regarding their future profession (see Appendix 3). The questionnaire was designed for first and second study cycle translation students and distributed at one university. In total, 40 completed questionnaires were received. However, considering that there are three main institutions training translators in Lithuania, the data obtained may be considered to be representative to a certain extent. All three questionnaires were designed to include both closed questions with answer options ranging from strongly agree to strongly disagree and open questions in order to encourage respondents to 
Kasperè, R. and Motiejūnienè, J. (2021). Impacts of global pandemic on translator's career and translator training. Current Trends in Translation Teaching and Learning E, 8, 154 - 195. https://doi.org/10.51287/cttle 20216

express opinions and attitudes that may have eluded our preliminary assumptions.

\section{RESULTS AND DISCUSSION}

The results indicated both positive and negative opinions in the three questionnaires. In the first two questionnaires of LSPs (see Appendix 1) and freelancers (see Appendix 2), a considerable decrease in the amount of orders was noted by all responders. More than four fifths of LSPs $(81 \%)$ and more than two thirds of freelancers (66\%) noticed a decrease in the number of requests and orders, respectively, over the first two months of the lockdown (see Figs. 1 and 2 ). And of them, more than half felt that the number of orders decreased by $40 \%$ and even more.

Figure 1. Responses of heads of LSPs regarding the decrease of requests over the first two months of the lockdown

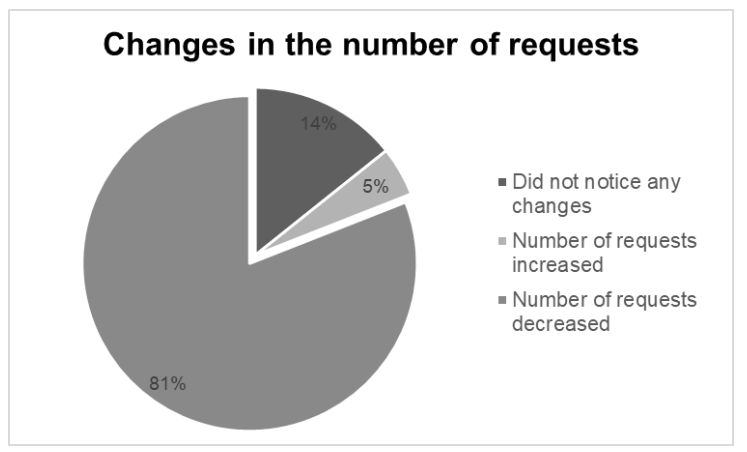


Kasperè, R. and Motiejūnienè, J. (2021). Impacts of global pandemic on translator's career and translator training. Current Trends in Translation Teaching and Learning E, 8, 154 - 195. https://doi.org/10.51287/cttle 20216

Figure 2. Responses of freelance translators and interpreters regarding the change of orders over the first two months of the lockdown

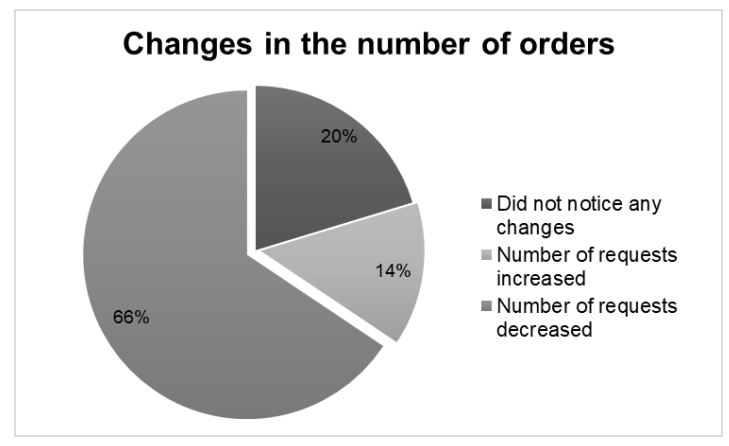

LSPs also indicated that there was a considerable loss of regular clients (see Figure 3). However, the main impact and losses were felt in relation to interpreting rather than translation. Freelancers and heads of LSPs thought that, in the short-term, the impact was damaging since the workload decreased and some clients retreated. However, the responders were generally positive and felt that everything would come back to normal in the long-term. Professional translators with long-term experience responded that they felt that they would not be severely affected and would always have a lot of work. 
Kasperè, R. and Motiejūnienè, J. (2021). Impacts of global pandemic on translator's career and translator training. Current Trends in Translation Teaching and Learning E, 8, 154 - 195. https://doi.org/10.51287/cttle 20216

Figure 3. Responses of heads of LSPs regarding the loss of regular clients over the first two months of the lockdown

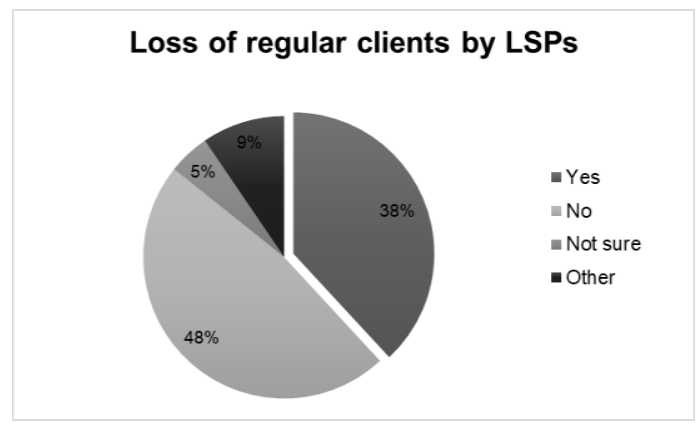

Another question asked in the survey was about any changes in the prices of translations. The vast majority of freelancers $(85 \%)$ indicated that they did not change prices for translation in relation to the COVID-19 pandemic and the lockdown. $10 \%$ indicated that they reduced the prices and $5 \%$ indicated that they increased the prices due to the pandemic and lockdown situation. Meanwhile, more than half $(67 \%)$, but fewer than freelancers $(85 \%)$, LSPs indicated that they did not change prices (see Figure 4). 
Kasperè, R. and Motiejūnienè, J. (2021). Impacts of global pandemic on translator's career and translator training. Current Trends in Translation Teaching and Learning E, 8, 154 - 195. https://doi.org/10.51287/cttle 20216

Figure 4. Responses of LSPs regarding the changes in prices

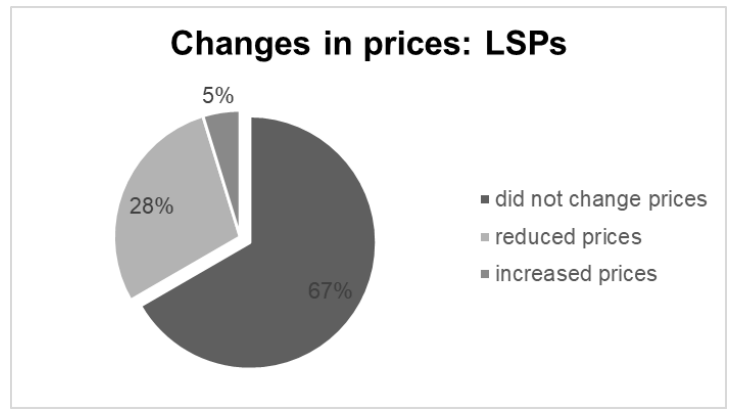

Another point to note is the noticed change in the number of translation text domains. The majority of freelancers noticed an increase in the number of orders on the COVID-19 topic and generally medicine.

The majority of freelancers $(80 \%)$ indicated that they knew about the state support. Of them, $48 \%$ indicated having obtained the state support and $32 \%$ indicated that they did not intend to apply for it. Only $19 \%$ of freelancers did not know about the possible state support. Different patterns in freelancers' answers could be discerned with regard to translators who work for language service providers and those that work on their own. Generally, freelancers who work with LSPs and have contracts with a few agencies for translation jobs expressed more positive opinions and more trust in future cooperation with LSPs. 
Kasperè, R. and Motiejūnienè, J. (2021). Impacts of global pandemic on translator's career and translator training. Current Trends in Translation Teaching and Learning E, 8, 154 - 195. https://doi.org/10.51287/cttle 20216

Freelancers who work on their own tended to express less positive opinions towards the future stability in their profession.

When LSPs were asked to express their opinion about the impact of the pandemic on their workflows in the near future, the majority of them answered that the LSP would experience some negative effects sooner or later. In one of the answers, the respondent expressed fair that freelancers (translators and interpreters) might start looking for new jobs in other areas that ensure a stable income and that it might be difficult to get them back into the translation market later. There were some concerns expressed regarding smaller translation service providers, e.g.,

I have no doubt the impact of pandemic will be negative for smaller translation offices.

We anticipate that there may be more than one bankruptcy in the market.

Freelance translators on the contrary to LSPs expressed much more optimistic thoughts with regard to impacts of the pandemic and lockdown on the translation profession, e.g., 
Kasperè, R. and Motiejūnienè, J. (2021). Impacts of global pandemic on translator's career and translator training. Current Trends in Translation Teaching and Learning E, 8, 154 - 195. https://doi.org/10.51287/cttle 20216

I believe that the pandemic will have a positive impact on the work of the translator. There are more opportunities arising.

As translation work can be done remotely, the lockdown should not severely affect freelance translators in the near future.

The best translators will always have enough work.

The impact will not be severe. There may be more translations in the medical field.

The student survey (Appendix 3) was aimed at finding out future professionals' perceptions towards the training challenges, achievement of competences in current conditions and profession transformations. The answers to the survey indicated both positive and negative opinions. More than half of the students indicated that the change from a contact to a remote mode of studying affected their motivation and commitment to do their best in order to get most out of the study years (20\% strongly agreed and 37.5\% somewhat agreed), and that such a way of studying affected their intake of theoretical and practical knowledge in translation studies (see Figs. 5 and 6). Besides, $40 \%$ of students indicated that a remote 
Kasperè, R. and Motiejūnienè, J. (2021). Impacts of global pandemic on translator's career and translator training. Current Trends in Translation Teaching and Learning E, 8, 154 - 195. https://doi.org/10.51287/cttle 20216

\section{mode of studying affected their overall satisfaction with translation studies at the university.}

Figure 5. Responses of students to whether the change from a contact to a remote mode of studying affected their intake of theoretical knowledge in translation studies

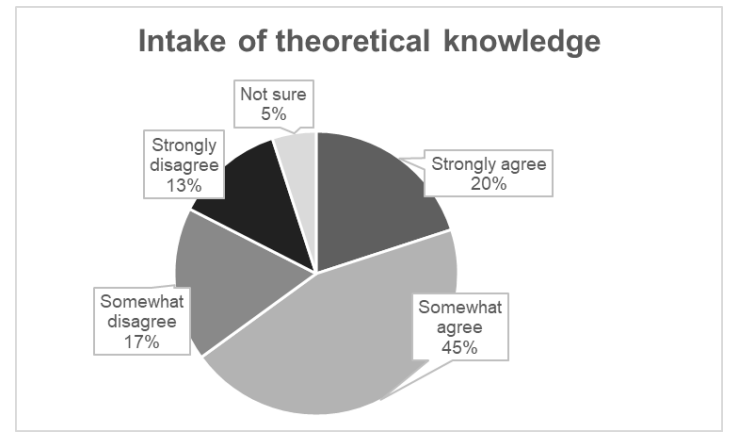

Figure 6. Responses of students to whether the change from a contact to a remote mode of studying affected their intake of practical skills in translation studies

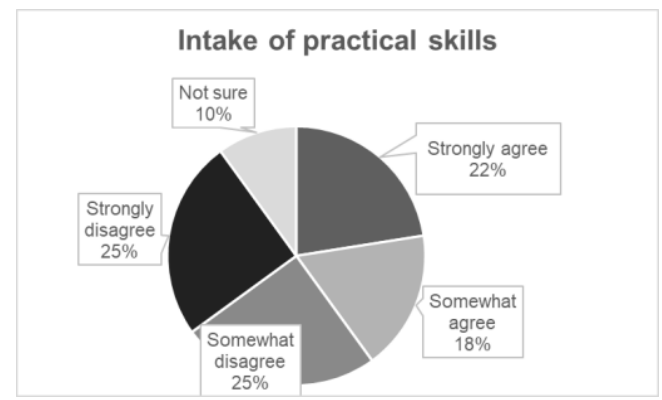


Kasperè, R. and Motiejūnienè, J. (2021). Impacts of global pandemic on translator's career and translator training. Current Trends in Translation Teaching and Learning E, 8, 154 - 195. https://doi.org/10.51287/cttle 20216

The skills and competences that need to be acquired by way of contact studying in students' opinion are simultaneous interpreting, practical translation skills and skills related to the use of computer-assisted translation tools and translation and localization software. Language competences were also mentioned by the students among those requiring contact studying. Overall, students felt that translation studies became more monotonous, some of them lost motivation and struggled keeping track of the tasks and deadlines. On the other hand, such weariness and fatigue with the remote mode of studying may be well expected in any kind of training.

However, a difference in opinions expressed through open questions could be discerned between bachelor and master students. The latter were more satisfied with remote studying. Master students usually have jobs and need to work during the day, so having remote classes is a more attractive option for them as it gives more flexibility, e.g.,

For master students, it allows to fully handle work and studies by saving time and being able to connect whether you are at work or you must leave to another city. 
Kasperè, R. and Motiejūnienè, J. (2021). Impacts of global pandemic on translator's career and translator training. Current Trends in Translation Teaching and Learning E, 8, 154 - 195. https://doi.org/10.51287/cttle 20216

In the survey, students were also asked several open questions regarding their engagement into learning activities in the remote mode of studies. Undergraduate students were asked to provide insights into what kept them engaged in translation courses organised remotely due to the pandemic. Students noted that they were able to stay engaged when their lecturers used different ways to keep their attention, such as requiring everyone to turn their cameras on, which prevented from doing something else during the class, or telling a joke, delivering information as simply as possible and allowing flexible deadlines for doing homework. Students were also asked what made them disappointed in the remote mode learning. In addition to mentioning technical problems and lack of face to face communication, students also mentioned that it was disappointing not to have group work activities. It should be mentioned that this last problem could easily be solved by assigning group work activities to be done remotely. We also asked students to comment on the ways that would keep them engaged in the remote classes in order to achieve best results. Students mentioned their wish for the teachers to communicate with them in a more inclusive way, come up with more creative tasks and provide individual consultations, e.g., 
Kasperè, R. and Motiejūnienè, J. (2021). Impacts of global pandemic on translator's career and translator training. Current Trends in Translation Teaching and Learning E, 8, 154 - 195. https://doi.org/10.51287/cttle 20216

I think coming up with more creative tasks and learning methods would help me to be more engaged in this module as well as to achieve better results.

The majority of graduate students said that they did not encounter any problems in the remote mode of studies and that they saw many benefits in it, e.g., the ability to manage their time in a more efficient way or juggling work and school, e.g.,

I strongly believe that remote mode shouldn't be portrayed as a necessarily worse way of learning than a contact mode. I think it comes down more to self-motivation and self-management skills of a person; if a student is willing to learn, (s)he will learn even on remote mode of studies.

As some possible ways to improve the knowledge and skills intake during the remote mode of studies, students mentioned creating positive atmosphere, setting up more creative tasks and using more visual information in slides in order for them to capture information in easier ways. As some of the drawbacks of the remote mode of learning, students mentioned technical problems and lack of access to some translation software, e.g., 
Kasperè, R. and Motiejūnienè, J. (2021). Impacts of global pandemic on translator's career and translator training. Current Trends in Translation Teaching and Learning E, 8, 154 - 195. https://doi.org/10.51287/cttle 20216

The biggest disadvantage of courses organised remotely was the fact that I could not get access to all the tools that were available at the university.

It was difficult for me to translate while not having all CAT tools, e.g., Trados.

What looks promising is that there are not many students who feel that the overall quality of their translation studies will decrease if the lockdown continues for another few months (see Figure 7). On the other hand, in order to keep to the expectations, trainers need to reconsider and find the best ways how to deliver the content and teach the skills at the same time reducing remote work fatigue and maintaining students' motivation and commitment, the challenges that are experienced in any field. 
Kasperè, R. and Motiejūnienè, J. (2021). Impacts of global pandemic on translator's career and translator training. Current Trends in Translation Teaching and Learning E, 8, 154 - 195. https://doi.org/10.51287/cttle 20216

Figure 7. Responses of students regarding a possible decrease of the overall quality of translation studies if the lockdown continues

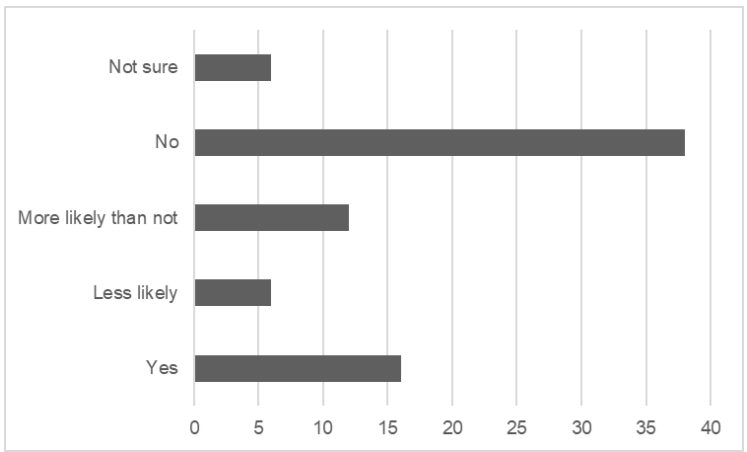

Students were also asked an open question regarding their perceptions about their future profession after the global pandemic. Many of them (both undergraduates and graduates) were positive towards the future. They claimed to be aware that the translator's profession allows working from home or anywhere and office work is a rarity. Therefore, pandemics and lockdowns do not have a big impact on the working conditions, e.g.,

I'm a freelance translator, so my work is done from home anyway. In the meantime, the demand for translations still seems high. There is no shortage of work. 
Kasperè, R. and Motiejūnienè, J. (2021). Impacts of global pandemic on translator's career and translator training. Current Trends in Translation Teaching and Learning E, 8, 154 - 195. https://doi.org/10.51287/cttle 20216

I think translators can enjoy the possibility to work from home, as many have done until now. There is no need to worry about the risk of infection, as, for example, those who work in the trade. I am sure that some people may have lost work because the clients they are translating for have gone out of business or something like that, but translators are flexible and can look for other clients. I think that is something that they will be doing for some time to come - looking for new clients. And that is the daily routine of many freelancers.

It might be assumed that students understand well the specifics of their profession and do not expect any changes in terms of the working conditions, either induced by crises or any other effects. 
Kasperè, R. and Motiejūnienè, J. (2021). Impacts of global pandemic on translator's career and translator training. Current Trends in Translation Teaching and Learning E, 8, 154 - 195. https://doi.org/10.51287/cttle 20216

\section{CONCLUSION}

Although further research is necessary to investigate the means of relieving the negative effects experienced by the translators already working in the trade and translation students, the results of the surveys highlight varying opinions of translation students and freelance translators towards the future of the profession, trust of freelance translators towards the state support and translation agencies at which they are hired, and anxiety of language service providers towards the stability of the industry. Translation studies have recently been focusing on interdisciplinary approaches, combining language studies, technology, IT, business management, etc. One new area to concentrate on in the future could be the psychological aspects, e.g., learning to cope with sudden changes in society.

The findings obtained in this study are in agreement with collected reactions of translators from all over the world (CEATL, 2020; Wang, 2020). However, the empirical research on the topic is still scarce, thus showing the need for further research, especially in the long-term perspective. The data showed that the issue under analysis was complex and rather ambiguous as some freelance translators and translation trainees experienced negative effects while others observed positive effects. Based on the 
Kasperè, R. and Motiejūnienè, J. (2021). Impacts of global pandemic on translator's career and translator training. Current Trends in Translation Teaching and Learning E, 8, 154 - 195. https://doi.org/10.51287/cttle 20216

results of this study that in general show more confidence and optimism towards the future of the translators' profession, we think that it is necessary to help translation trainees to develop a wider skillset and be ready to adapt in crisis settings. A remote way of studying has been a challenge requiring additional efforts not only on the instructors' part, but also on the students' part. At the same time, the challenges of the past years of constant adaptation to the changing circumstances and transformations have to be a lesson learned on both parts - the academia and the trade understanding that changes are imminent and have to be confronted and dealt with without hesitation. 
Kasperè, R. and Motiejūnienè, J. (2021). Impacts of global pandemic on translator's career and translator training. Current Trends in Translation Teaching and Learning E, 8, 154 - 195. https://doi.org/10.51287/cttle 20216

\section{REFERENCES}

Alexander, D.E. \& Pescaroli, G. (2019). The role of translators and interpreters in cascading crises and disasters: Towards a framework for confronting the challenges. Disaster Prevention and Management, 29(2), 144-156. https://doi.org/10.1108/DPM-12-2018-0382

Dalzell, S. (2020). Federal Government used Google Translate for COVID-19 messaging aimed at multicultural communities. $A B C N e w s$. https://www.abc.net.au/news/2020-1119/government-used-google-translate-fornonsensical-covid-19-tweet/12897200

European Master's in Translation: Competence Framework 2017. (2017, May 22). EMT (European Master's in Translation). https://ec.europa.eu/info/resourcespartners/european-masters-translationemt/european-masters-translation-emtexplained_en

Federici, F.M. \& O’Brien, S. (Eds). (2019) Translation in Cascading Crises. London: Routledge. 
Kasperè, R. and Motiejūnienè, J. (2021). Impacts of global pandemic on translator's career and translator training. Current Trends in Translation Teaching and Learning E, 8, 154 - 195. https://doi.org/10.51287/cttle 20216

Federici, F.M. \& Cadwell, P. (2018). Training citizen translators: Design and delivery of bespoke training on the fundamentals of translation for New Zealand Red Cross. Translation Spaces, 7(1), 20-43.

https://doi.org/10.1075/ts.00002.fed

Krajcso, Z. (2018). Translators' competence profiles versus market demand. Babel, 64(5-6), 692709.

https://doi.org/10.1075/babel.00059.kra

Le Plouhinec, V. (2020, April 8). European overview of translation under the Covid-19 crisis, Conseil Européen des Associations de Traducteurs Littéraires. CEATL.

https://www.ceatl.eu/european-overview-of$\underline{\text { translation-under-the-covid-19-crisis }}$

Luo, X. (2021). Translation in the time of COVID-19. Asia Pacific Translation and Intercultural Studies, 8(1), 1-3.

https://doi.org/10.1080/23306343.2021.1903 $\underline{183}$

O’Brien, S. \& Federici, F.M. (2020). Crisis translation: considering language needs in multilingual disaster settings. Disaster Prevention and Management, 29(2), 129-143. 
Kasperè, R. and Motiejūnienè, J. (2021). Impacts of global pandemic on translator's career and translator training. Current Trends in Translation Teaching and Learning E, 8, 154 - 195. https://doi.org/10.51287/cttle 20216

\section{https://doi.org/10.1108/DPM-11-2018-0373}

O’Mathúna, D.P., Escartín, C.P., Roche, P., Marlowe,

J. (2020). Engaging citizen translators in disasters. Virtue ethics in response to ethical challenges. Translation and Interpreting Studies, 15(1), 57-79.

https://doi.org/10.1075/tis.20003.oma

O'Shea, J. (2020, March 18). Measures around Europe in response to COVID-19 to support interpreters and translators.

http://fit-europe-rc.org/en/measures-aroundeurope-in-response-to-covid-19-to-supportinterpreters-and-translators/

Piekkari, R., Tietze, S., Angouri, J., Meyer, R. \& Vaara, E. (2021). Can you Speak Covid-19? Languages and Social Inequality in Management Studies. Journal of Management Studies, 58, 587-591.

https://doi.org/10.1111/joms.12657

Rossetti, A., O'Brien, S. \& Cadwell, P. (2020, November 6). Comprehension and trust in crises: investigating the impact of machine translation and post-editing. $22^{\text {nd }}$ Annual Conference of the European Association for 
Kasperè, R. and Motiejūnienè, J. (2021). Impacts of global pandemic on translator's career and translator training. Current Trends in Translation Teaching and Learning E, 8, 154 - 195. https://doi.org/10.51287/cttle 20216

Machine Translation (EAMT 2020), Lisbon, Portugal.

https://aclanthology.org/2020.eamt-1.2

Rodríguez Vázquez, S. \& Torres-del-Rey, J. (2019). Accessibility of multilingual information in cascading crises. In F.M. Federici \& S. O'Brien (Eds.), Translation in cascading crises (pp. 91-111). Routledge. https://doi.org/10.4324/9780429341052

Translation services - Post-editing of machine translation output - Requirements (2017, April 12).

https://www.iso.org/standard/62970.html

Translation services - Requirements for translation services. (2015, April 24).

https://www.iso.org/standard/59149.html

Veliz-Ojeda, E., Yu, C., \& Wilson, R. (2020). The role of language technologies and government policies to facilitate and support effective multicultural and multilingual crisis communication. Research Brief. Monash University, Clayton Vic Australia. https://www.monash.edu/_data/assets/pdf_fi le/0008/2349044/MIL-RESEARCHBRIEF_SEPTEMBER-2020-V6.pdf 
Kasperè, R. and Motiejūnienè, J. (2021). Impacts of global pandemic on translator's career and translator training. Current Trends in Translation Teaching and Learning E, 8, 154 - 195. https://doi.org/10.51287/cttle 20216

Wang, L., Sun, J., Ren, J., \& Meng, Y. (2020, April 1). How are language service providers affected by COVID-19? Language on the move.

https://www.languageonthemove.com/howare-language-service-providers-affected-bycovid-19/

Zhang, J. \& Wu, Y. (2020). Providing multilingual logistics communication in COVID-19 disaster relief. Multilingua, 39(5), 517-528. https://doi.org/10.1515/multi-2020-0110

Zheng, Y. (2020). Mobilizing foreign language students for multilingual crisis translation in Shanghai. Multilingua, 39(5), 587-595. https://doi.org/10.1515/multi-2020-0095

\section{APPENDIX 1. Survey of LSPs on the effects of the pandemic and lockdown}

1. How many freelance translators does your LSP cooperate with?

a. Fewer than 50

b. $50-100$

c. More than 100

2. Where is your LSP located? 
Kasperè, R. and Motiejūnienè, J. (2021). Impacts of global pandemic on translator's career and translator training. Current Trends in Translation Teaching and Learning E, 8, 154 - 195. https://doi.org/10.51287/cttle 20216
a. Vilnius
b. Kaunas
c. Other

3. Have you noticed any changes in the number of translation orders in the last 2 months?

a. The number of orders increased.

b. The number of orders decreased.

c. I have not noticed any changes in the number of orders.

d. Other

4. If the number of translation orders has increased in the last two months, what is the approximate percentage of the increase?
a. Up to $10 \%$
b. $10-20 \%$
c. $20-30 \%$
d. $30-40 \%$
e. $40-50 \%$
f. More than $50 \%$

5. If the number of translation orders has decreased in the last two months, what is the approximate percentage of the decrease?
a. Up to $10 \%$
b. $10-20 \%$
c. $20-30 \%$
d. $30-40 \%$ 
Kasperè, R. and Motiejūnienè, J. (2021). Impacts of global pandemic on translator's career and translator training. Current Trends in Translation Teaching and Learning E, 8, 154 - 195. https://doi.org/10.51287/cttle 20216
e. $40-50 \%$
f. More than $50 \%$

6. Have you noticed any changes in the nature of the texts you have been requested to translate in the last 2 months?
a. Yes
b. No
c. Other

7. If you notice that the nature of the texts you have been requested to translate has changed, please indicate how. (open question)

8. Have you noticed any changes in translation requests for the language pairs?
a. Yes
b. No
c. Other

9. If you have noticed a change in the requests for translation involving specific language pairs in the last 2 months, please indicate language pairs which have increased and/or decreased. (open question)

10. Have you changed prices for translation in the last 2 months?

a. As an LSP, we have increased the price.

b. As an LSP, we have decreased the price. 
Kasperè, R. and Motiejūnienè, J. (2021). Impacts of global pandemic on translator's career and translator training. Current Trends in Translation Teaching and Learning E, 8, 154 - 195. https://doi.org/10.51287/cttle 20216

c. As an LSP, we have not changed the price.

11. Have you lost any regular clients because of the pandemic and lockdowns?
a. Yes
b. No
c. Other

12. If you have lost any regular clients because of the pandemic and lockdowns, what is the approximate percentage of this loss?
a. Up to $10 \%$
b. $10-20 \%$
c. $20-30 \%$
d. $30-40 \%$
e. $40-50 \%$
f. More than $50 \%$

13. What is your opinion about the impact of the pandemic on the LSP workflows in the near future? (open question)

14. What is your general opinion about the impact of this pandemic on the translation profession in the near future? (open question) 
Kasperè, R. and Motiejūnienè, J. (2021). Impacts of global pandemic on translator's career and translator training. Current Trends in Translation Teaching and Learning E, 8, 154 - 195. https://doi.org/10.51287/cttle 20216

\section{APPENDIX 2. Survey of freelance translators on the effects of the pandemic and lockdown}

1. Is translation your main source of income?
a. Yes
b. No
c. Other

2. Do you cooperate with translation agencies?
a. Yes
b. No
c. Other

3. Do you cooperate with several translation agencies?
a. With one
b. With two
c. With three
d. With more than three
e. I do not cooperate with any.
f. Other

4. Have you noticed any changes in the number of translation orders in the last 2 months?

a. The number of orders increased.

b. The number of orders decreased.

c. I have not noticed any changes in the number of orders.

d. Other 
Kasperè, R. and Motiejūnienè, J. (2021). Impacts of global pandemic on translator's career and translator training. Current Trends in Translation Teaching and Learning E, 8, 154 - 195. https://doi.org/10.51287/cttle 20216

5. If the number of translation orders has increased in the last two months, what is the approximate percentage of the increase?
a. Up to $10 \%$
b. $10-20 \%$
c. $20-30 \%$
d. $30-40 \%$
e. $40-50 \%$
f. More than $50 \%$

6. If the number of translation orders has decreased in the last two months, what is the approximate percentage of the decrease?
a. Up to $10 \%$
b. $10-20 \%$
c. $20-30 \%$
d. $30-40 \%$
e. $40-50 \%$
f. More than $50 \%$

7. Have you noticed any changes in the nature of the texts you have been requested to translate in the last 2 months?
a. Yes
b. No
c. Other 
Kasperè, R. and Motiejūnienè, J. (2021). Impacts of global pandemic on translator's career and translator training. Current Trends in Translation Teaching and Learning E, 8, 154 - 195. https://doi.org/10.51287/cttle 20216

8. If you notice that the nature of the texts you have been requested to translate has changed, please indicate how. (open question)

9. If you work with more than one language pair, have translation requests for the language pairs changed?
a. Yes
b. No
c. Other

10. If you have noticed a change in the requests for translation involving specific language pairs in the last 2 months, please indicate language pairs which have increased and/or decreased. (open question)

11. Have you changed prices for translation in the last 2 months?
a. I have increased the price.
b. I have decreased the price.
c. I have not changed the price.

12. Are you aware of any state support for the COVID19 pandemic to help freelancers?
a. Yes, I know and I intend to apply for it.
b. Yes, I know but I do not intend to apply.
c. No, I do not know about the state support.
d. Other 
Kasperè, R. and Motiejūnienè, J. (2021). Impacts of global pandemic on translator's career and translator training. Current Trends in Translation Teaching and Learning E, 8, 154 - 195. https://doi.org/10.51287/cttle 20216

13. What is your general opinion about the impact of this pandemic on the translation profession in the near future? (open question)

\section{APPENDIX 3. Survey on the effects of lockdown experienced by translation students}

1. Which cycle of translation studies are you enrolled in?

a. Bachelor studies

b. Master studies

2. Which is the year of your translation studies?
a. First
b. Second
c. Third
d. Fourth

3. Has the change from a contact to a remote mode of studying affected your motivation and commitment to do your best in order to get most out of the study years?
a. Strongly agree
b. Somewhat agree
c. Somewhat disagree
d. Strongly disagree
e. Not sure 
Kasperè, R. and Motiejūnienè, J. (2021). Impacts of global pandemic on translator's career and translator training. Current Trends in Translation Teaching and Learning E, 8, 154 - 195. https://doi.org/10.51287/cttle 20216

4. Has the change from a contact to a remote mode of studying affected your intake of theoretical knowledge in translation studies?

a. Strongly agree

b. Somewhat agree

c. Somewhat disagree

d. Strongly disagree

e. Not sure

5. Has the change from a contact to a remote mode of studying affected your intake of practical translation skills?
a. Strongly agree
b. Somewhat agree
c. Somewhat disagree
d. Strongly disagree
e. Not sure

6. Has the change from a contact to a remote mode of studying affected your overall satisfaction with translation studies at the university?
a. Strongly agree
b. Somewhat agree
c. Somewhat disagree
d. Strongly disagree
e. Not sure 
Kasperè, R. and Motiejūnienè, J. (2021). Impacts of global pandemic on translator's career and translator training. Current Trends in Translation Teaching and Learning E, 8, 154 - 195. https://doi.org/10.51287/cttle 20216

7. Name the competence which in your opinion could be more easily and efficiently acquired if the studies were organised as contact. (open question)

8. Do you think that the overall quality of your translation studies has decreased because of the lockdown and remote studies?

a. Strongly agree

b. Somewhat agree

c. Somewhat disagree

d. Strongly disagree

e. Not sure

9. Do you think that the overall quality of your translation studies will decrease if the lockdown continues for another few months?
a. Yes
b. More likely than not
c. Less likely
d. No
e. Not sure

10. What is the greatest challenge while studying translation remotely? (open question)

11. In what other ways has the lockdown affected your studies in a translation programme? Write down 
Kasperè, R. and Motiejūnienè, J. (2021). Impacts of global pandemic on translator's career and translator training. Current Trends in Translation Teaching and Learning E, 8, 154 - 195. https://doi.org/10.51287/cttle 20216

your general opinion about the quality of studies during the pandemic. (open question)

12. What kept you engaged in translation courses organised remotely due to the pandemic? (open question)

13. What made you disappointed in translation courses organised remotely due to the pandemic? (open question) 